\title{
Flabelligena gascognensis sp. nov. (Polychaeta: Acrocirridae), a new species from the Capbreton Canyon (Bay of Biscay, NE Atlantic)
}

\author{
FLORENCIO AGUIRREZABALAGA and ARGILOA CEBERIO
}

S.C. INSUB, Zemoriya 12, Apdo 3223, 20013 Donostia-San Sebastián, Spain. E-mail: p.agirrezabalaga@ehu.es

\begin{abstract}
SUMMARY: Flabelligena gascognensis (Annelida: Polychaeta), a new species of the family Acrocirridae Banse, 1969 is described from the northeastern Atlantic. The specimens were collected from the Capbreton Canyon, Bay of Biscay, at depths between 545 and $1113 \mathrm{~m}$. The new species has three pairs of branchiae and a pair of large ventral papillae. A light emendation of the diagnosis of the genus is proposed with the aim of including the new species and two other species, Flabelligella mediterranea Kolmer, 1985 and Flabelligella biscayensis Kolmer, 1985, into the genus Flabelligena. A key and a comparative table of the main characters of the known species of the genus are also included.
\end{abstract}

Keywords: Polychaeta, Acrocirridae, Flabelligena, new species, Bay of Biscay.

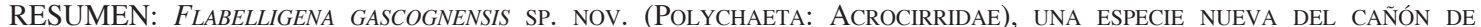
Capbreton (Golfo de Vizcaya, AtlánTico NE). - Flabelligena gascognensis (Annelida: Polychaeta), una nueva especie de la familia Acrocirridae Banse, 1969 que se describe del Atlántico NE. Los ejemplares fueron recolectados en el Cañón de Capbretón entre 545 y 1113 m de profundidad. La nueva especie tiene tres pares de branquias y un par de grandes papilas ventrales. Se propone una pequeña enmienda en la diagnosis del género, con objeto de incluir la nueva especie y dos más, Flabelligella mediterranea Kolmer,1985 y Flabelligella biscayensis Kolmer,1985, dentro del género Flabelligena. Se incluyen una clave y una tabla comparativa de los principales caracteres de las especies conocidas del género.

Palabras clave: Polychaeta, Acrocirridae, Flabelligena, especie nueva, Golfo de Vizcaya.

\section{INTRODUCTION}

The family Acrocirridae was created by Banse (1969) and currently contains four genera: Acrocirrus, Flabelligella, Flabelligena and Macrochaeta (Fauchald, 1977; Pettibone, 1982; Wolf, 1984; Blake, 1996; Gillet, 2001).

The genus Flabelligella Hartman, 1965, was initially placed in the family Flabelligeridae, and later in the family Fauveliopsidae (Hartman, 1971). Soon after, Orensanz (1974) emended the diagnosis of the family Acrocirridae and included the genus
Flabelligella in this family. Eight species had been described belonging to the genus Flabelligella (Hartman, 1965; Hartman and Fauchald, 1971; Fauchald, 1972; Orensanz, 1974; Kolmer, 1985). Finally, Gillet (2001) erected the new genus Flabelligena, which included species belonging to the genus Flabelligella bearing a pair of palps [branchiae in Orensanz (1974), Kolmer (1985) and Blake (1996)] and spinulose notochaetae.

At three bathyal stations situated on the continental slope of the Capbreton Canyon 270 specimens of a new species of the genus Flabelligena, which has 
three pairs of branchiae, were collected. The new species of Flabelligena is described, raising the number of known species to six. A light emendation of the diagnosis of the genus is proposed with the aim of including the new species, and Flabelligella mediterranea Kolmer, 1985 and Flabelligella biscayensis Kolmer, 1985 in the genus Flabelligena. A key and a comparative table of the main characters of the known species of the genus are also included.

\section{MATERIAL AND METHODS}

Specimens were collected at three stations situated in the Capbreton Canyon. Those of the station DI-12, situated between 1012 and $1113 \mathrm{~m}$ depth, were obtained using a Sanders-Hessler epibenthic dredge. The stations OB6-E'-TS09, situated between 756 and $795 \mathrm{~m}$ depth, and OB10-B-TS07, situated between 545 and $572 \mathrm{~m}$ depth, were sampled using a Roscoff suprabenthic sled (Dauvin et al., 1995). Both types of gear had a mesh size of 0.5 $\mathrm{mm}$. The samples were sieved through a $0.5 \mathrm{~mm}$ screen. Specimens were preserved in a $10 \%$ formaldehyde-seawater solution.

Type material has been deposited in the following institutions: Museo Nacional de Ciencias Naturales, Madrid (MNCN), Muséum National d’Histoire Naturelle, Paris (MNHN), Université Catholique de l'Ouest (UCO), and Sociedad Cultural de Investigación Submarina, San Sebastian (INSUB)

\section{SYSTEMATICS}

Fam. ACROCIRRIDAE Banse, 1969

Flabelligena gascognensis sp. nov. (Figs. 1-6)

\begin{abstract}
Material examined: Atlantic Ocean, Bay of Biscay, Capbreton Canyon, $43^{\circ} 50.09^{\prime} \mathrm{N} 2^{\circ} 03.23^{\prime} \mathrm{W}$ to $43^{\circ} 49.14^{\prime} \mathrm{N} 2^{\circ} 02.64^{\prime} \mathrm{W}, 572-545$ $\mathrm{m}$, soft bottom, R/V Côtes de la Manche, OXYBENT 10 stn OB10B-TS07, 29 April 2000, holotype (MNCN 16.01/10104) and 203 paratypes (MNCN 16.01/10105 2 paratypes) (MNHN XXXX 2 paratypes) (INSUB POL-178). Same, $43^{\circ} 36.30^{\prime} N^{\circ} 1^{\circ} 45.99^{\prime} \mathrm{W}$ to 43ํำ.79 $\mathrm{N} 1^{\circ} 47.33^{\prime} \mathrm{W}, 756-795 \mathrm{~m}$, soft bottom, R/V Côtes de la Manche, OXYBENT 6 stn OB6-E'-TS09, 7 December 1998, 24 paratypes (UCO XXXX 2 paratypes) (INSUB POL-179). Same, $43^{\circ} 38.57^{\prime} \mathrm{N} 2^{\circ} 17.3^{\prime} \mathrm{W}$ to $43^{\circ} 38.33^{\prime} \mathrm{N} 2^{\circ} 18.11^{\prime} \mathrm{W}, 1012-1113 \mathrm{~m}$, soft bottom, R/V Côte d'Aquitaine, CAPBRETON 88 stn DI-12, 6 July 1988, 42 specimens, (INSUB POL-180).
\end{abstract}

Description: Two hundred and seventy specimens, all incomplete. Holotype, length $7.85 \mathrm{~mm}$,

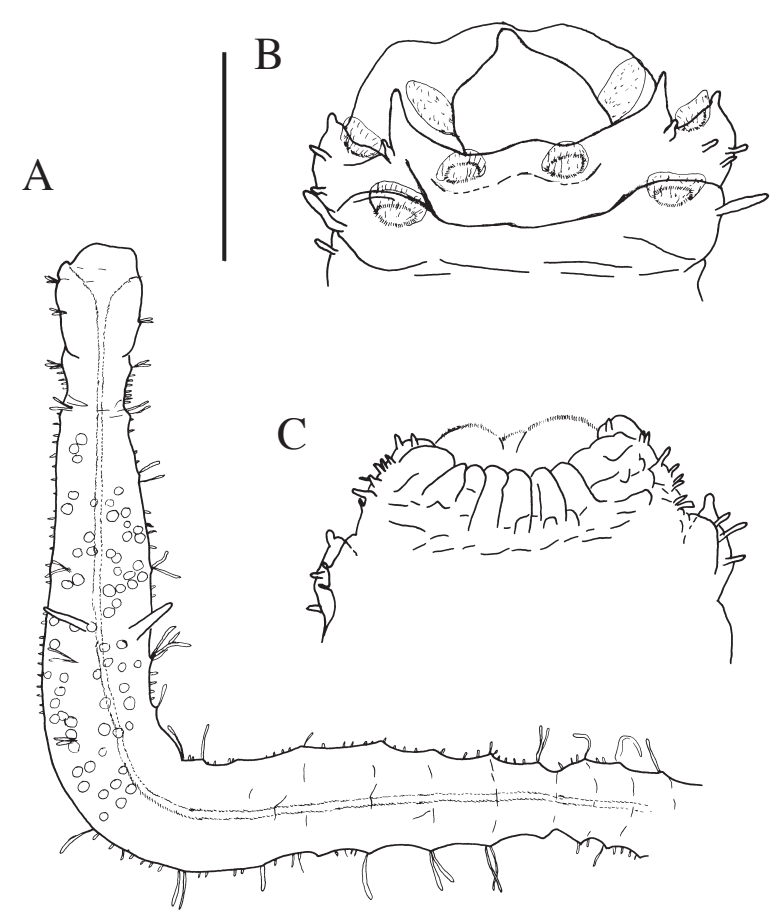

FIG. 1. - Flabelligena gascognensis sp. nov.; A, anterior region, ventral view; $\mathrm{B}$, anterior part, dorsal view; scars and remains of branchiae and frontal palps are added; $\mathrm{C}$, anterior part, ventral view. Scale $=$ A, $2500 \mu \mathrm{m} ; \mathrm{B}, \mathrm{C}, 500 \mu \mathrm{m}$.

maximum width $1.19 \mathrm{~mm}, 14$ chaetigers. Length of paratypes $2.07-15.41 \mathrm{~mm}$. Maximum width 0.43 $1.71 \mathrm{~mm}, 9-25$ chaetigers.

Body cylindrical, dorsal and ventral surface covered with cylindrical, thin papillae distally slightly enlarged (Figs. 1A, 3D, 4A, B, 5A, 6). Ventrally, two central, parallel lines that go across the body and as is observed in F. mediterranea, in the anterior region of the body diverge taking a Y- shape (Figs. 1A, 4A).

Anterior region, until chaetiger 4 inclusive, slightly slender. From chaetiger 5 to $8-9$ body more inflated, afterwards becoming slender. Some individuals with ova situated in body cavity between chaetigers 5 and 8-9 (Fig. 1A).

Prostomium subpentagonal, without eyes (Figs. 1B, 5A, B). Pair of short, globular frontal palps (Figs. 1B, 6). These are lost very easily and most individuals lack them.

Peristomium with pair of frontal branchiae; laterally to each branchia one lateral, triangular expansion, with one bottle-shaped papilla on external part of its base; next segment laterally ending in one expansion, with one papilliform button bearing one branchia (Figs. 1B, 4B, 5A,B, 6).

Second segment bearing one pair of lateral branchiae. As occurred with palps, branchiae are lost very easily and most individuals lack them. Scars of 


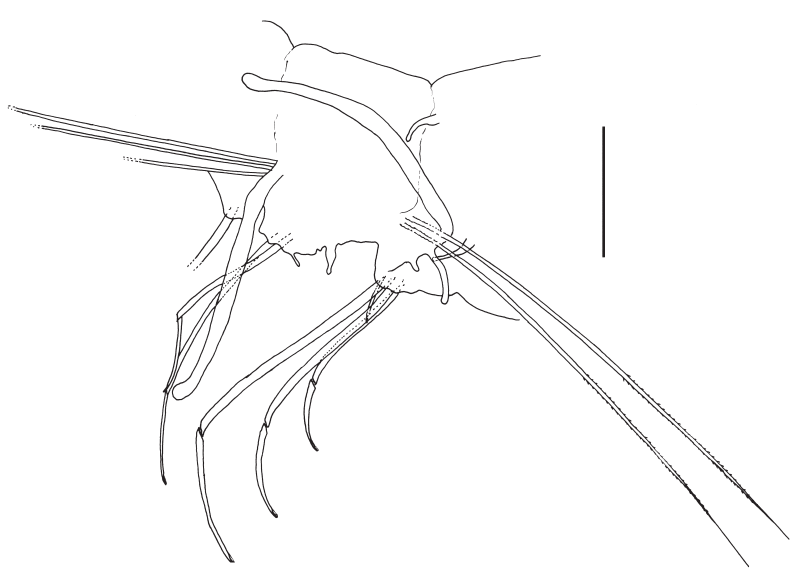

FIG. 2. - Flabelligena gascognensis sp. nov.; parapodia of middle region, lateral view. Scale $=400 \mu \mathrm{m}$.

attachment can be easily observed and in a very small number of individuals some brachiae or remains of them can also be observed (Figs. 1B, 4B, 5A, B).

Two large, cylindrical-conical ventral papillae between chaetigers 6 and 7 (Figs. 1A, 4A).

First chaetae from second segment (first chaetigerous segment). First two chaetigers unirrameous, only having neuropodium. From third chaetiger all chaetigers birrameous.

Notochaetae long, slender, spinulose capillary (Figs. 2, 3C), easily lost, with maximum number of four.

Two to four neurochaetae large, long composite falcigers, blade joined to shaft by membrane (Figs. 2, 3A). Blade long, distally curved, unidentate, distally covered with hyaline membranous cap. Inner edge of blade of some chaetae slightly denticulate (Figs. 3A, B), others smooth

Notopodium encircled by papillae similar in
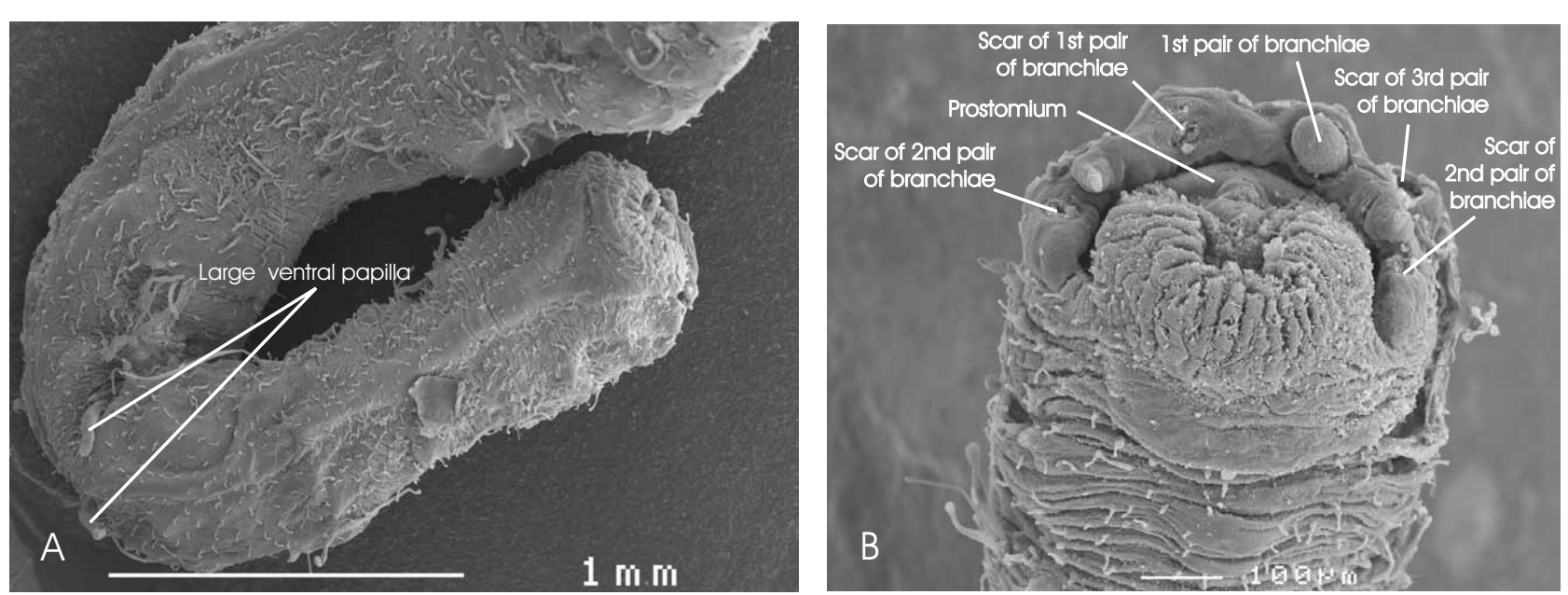

FIG. 4. - Flabelligena gascognensis sp. nov.; A, anterior region, ventral view; B, anterior part, ventral view. Scale = A, $1 \mathrm{~mm}$; B, $100 \mu \mathrm{m}$.

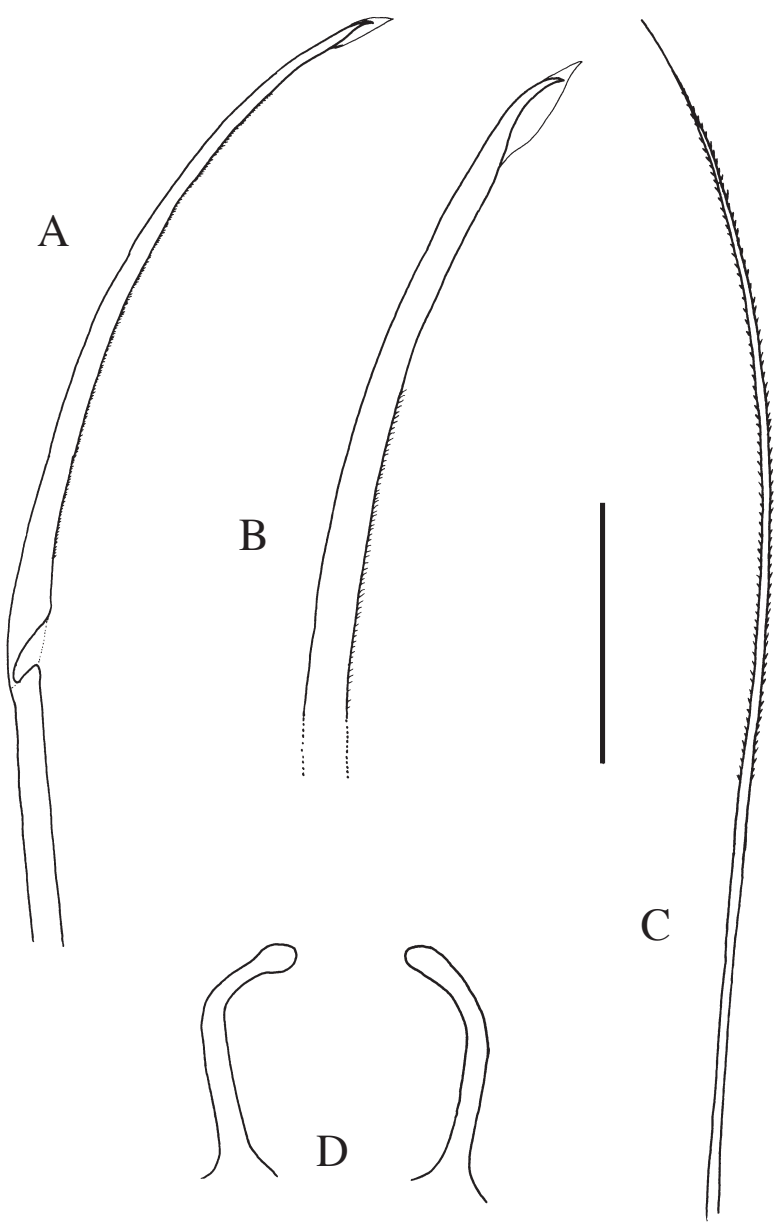

FIG. 3. - Flabelligena gascognensis sp. nov.; A, neuropodial composite falcigerous chaeta; B, detail of former neuropodial composite falcigerous chaeta; $C$, notopodial simple spinulose chaeta; D, papillae of body surface. Scale = A, D, $125 \mu \mathrm{m} ; \mathrm{B}, 50 \mu \mathrm{m} ; \mathrm{C}, 163 \mu \mathrm{m}$.

shape but larger and longer than those covering body surface (Fig. 2). Neuropodium with 2-3 papillae similar to those of body surface. 

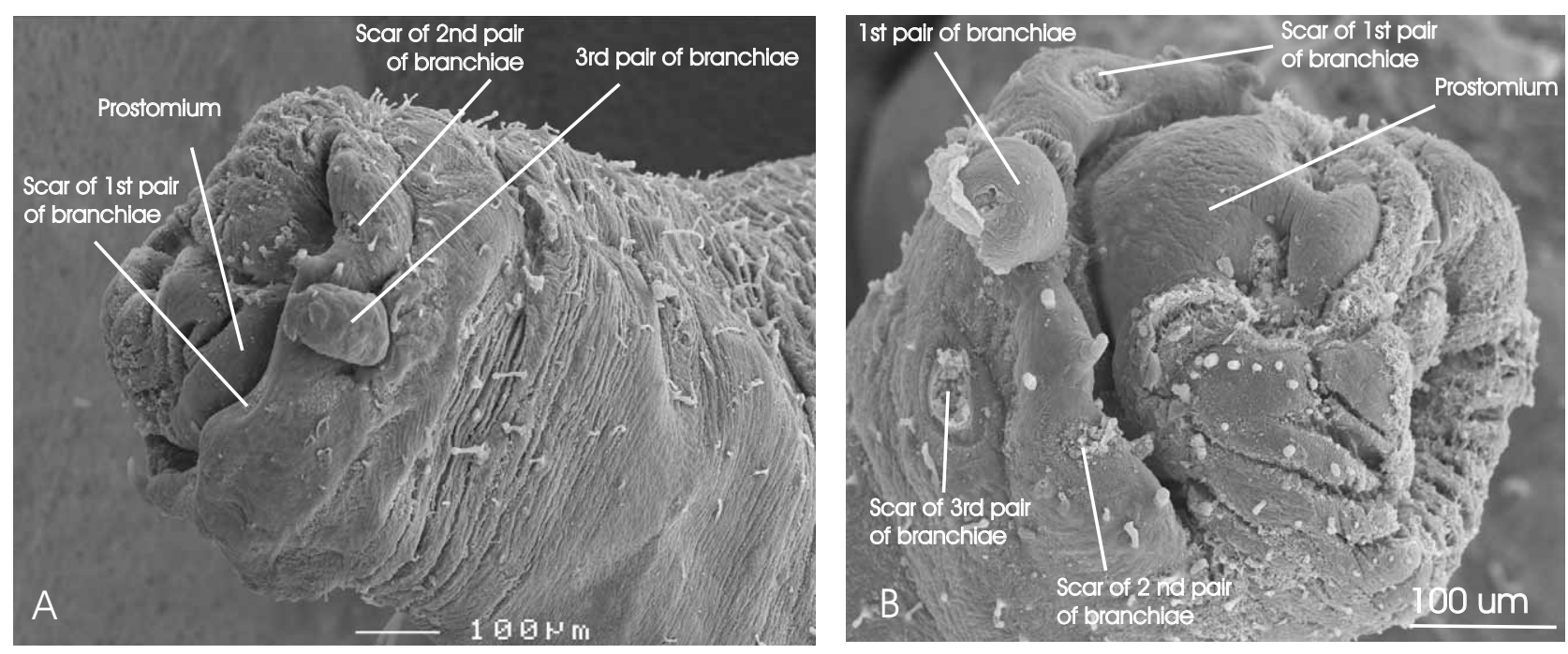

FIG. 5. - Flabelligena gascognensis sp. nov.; A, anterior part, dorso-lateral view; B, anterior part, dorso-frontal view. Scale $=100 \mu \mathrm{m}$.

Pygidium unknown.

Remarks: The presence of branchiae (three pairs) and spinulose notochaetae put our specimens into the genus Flabelligena Gillet, 2001.

Flabelligena gascognensis is closely related to Flabelligena erratica (Orensanz, 1974) and Flabelligena mediterranea (Kolmer, 1985). These three species have branchiae, a pair of large ventral papillae, and a similar shape/structure of the anteri- or end. However, F. erratica, like F. cirrata (Hartman and Fauchald, 1971) and F. amoureuxi Gillet, 2001, only has one pair of branchiae, whereas $F$. mediterranea [and $F$. biscayensis (Kolmer, 1985)] has two pairs and $F$. gascognensis has three pairs. Furthermore, in $F$. gascognensis, as in $F$. erratica, the pair of large ventral papillae is situated between chaetigers 6 and 7 rather than chaetigers 4 and 5, as occurs in F. mediterranea.

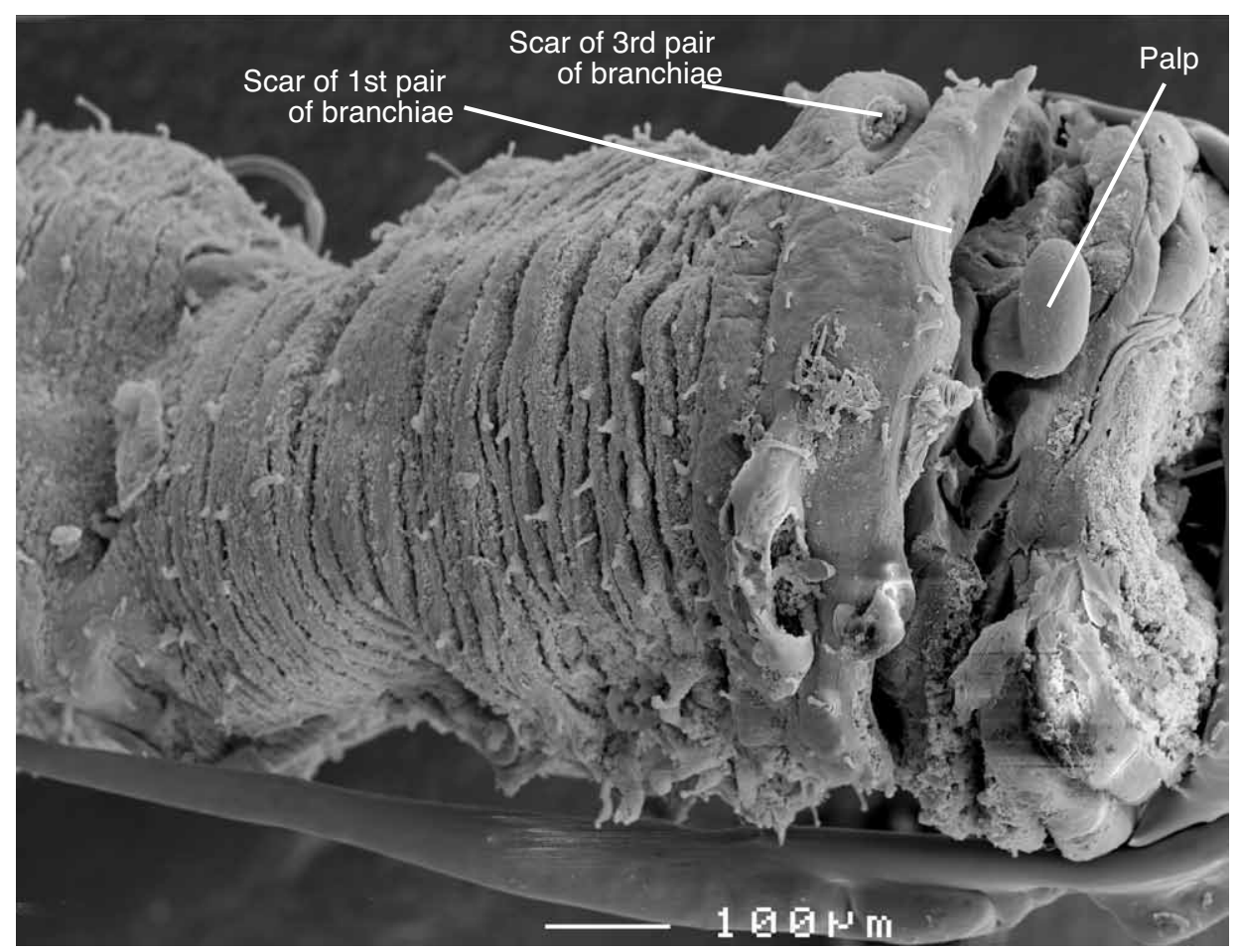

FIG. 6. - Flabelligena gascognensis sp. nov.; anterior region, dorsal view. Scale $=100 \mu \mathrm{m}$. 


\section{DISCUSSION}

The family Acrocirridae was created by Banse (1969) to include the genera Acrocirrus Grube, 1872 and Macrochaeta Grube, 1850, until then situated in the family Cirratulidae. The genus Flabelligella, originally placed in the family Flabelligeridae, was erected by Hartman (1965) and included two species: F. papillata and F. minuta. Among the main characteristics of the genus, Hartman indicated: "the anterior end lacks cage; surface epithelium with papillae; notopodia with simple, distally pointed, cross-barred setae; and neuropodia with composite falcigerous setae with distally hinged appendages".

Soon after this genus was included in the family Fauveliopsidae, and it was finally transferred by Orensanz (1974) to the family Acrocirridae. In this work, Orensanz described a new species (F. errati$c a$ ) and transferred the genus Flabelligella to the family Acrocirridae. He also emended slightly the diagnosis of the family as well as the genus. Among the main characteristics of the genus Flabelligella, Orensanz mentioned: “...Palpos frontales cortos y globosos, presentes al menos en una especie. Un par de cirros o branquias muy caducos presentes en al menos dos especies". ("Frontal palps short and spherical, present at least in one species. A pair of very deciduous cirri or branchiae present at least in two species"). [In Figure 1 on page 115, the presence and position of a pair of frontal palps and a pair of latero-dorsal appendages (cirri or branchiae according to Orensanz) can be observed very clear$l y]$. In addition to $F$. erratica, five species were considered by Orensanz as belonging to the genus, $F$. papillata, F. minuta, F. cirrata, F. macrochaeta and $F$. mexicana, so the other branchiate species would be $F$. cirrata. However, although some authors such as Light (1978) followed the ideas of Orensanz, in some recent important works the genus Flabelligella is defined as lacking branchiae or similar structures (Wolf, 1984; Blake, 1996), showing the confusion existing with regard to this genus.

Later, Kolmer (1985) described two new species, Flabelligella mediterranea and Flabelligella biscayensis, having two pairs of branchiae and spinulose notochaetae, and made a slight emendation of the genus (related to the number of branchiae) in order to include the new species. Finally, Gillet (2001) separated the Flabelligella species into two different genera: the genus Flabelligella, with the type species F. papillata Hartman, 1965, including the species without palps [branchiae in Orensanz (1974), Kolmer (1985) and Blake (1996)] and with cross-barred notochaetae ( $F$. mexicana, $F$. minuta and F. papillata); and the genus Flabelligena, with the type species F. cirrata (Hartman and Fauchald, 1971), including the species with a pair of palps [branchiae in Orensanz (1974), Kolmer (1985) and Blake (1996)] and spinulose or serrated notochaetae (F. amoureuxi, F. cirrata and F. erratica). Gillet does not include the species described by Kolmer (1985).

F. erratica, Flabelligella mediterranea Kolmer, 1985 and our specimens have similar characteristic (the shape of the anterior end, frontal palps, presence of a pair of large ventral papillae, cirri/branchiae, setae, etc.) and we think that they belong to the same genus. This genus would have palps and cirri/branchiae.

Taking into account the position of the palps (frontal) and cirri/branchiae (latero-dorsal, in the segment previous to the first chaetigerous segment) in F. erratica, in our opinion, the appendages of Flabelligella cirrata ["A pair of long, cirriform appendages is inserted between the peristomium and the first setigerous segment, in line with the parapodia" (Hartmann and Fauchald, 1971)] and Flabelligena amoureuxi Gillet, 2001, are not frontal appendages and would be equivalent to those considered as cirri/branchiae by Orensanz [Orensanz (1974) considered $F$. cirrata as a branchiate species]. In addition to the pair of appendages (cirri/branchiae), all these species (and F. biscayensis Kolmer, 1985) could have a pair of very deciduos frontal palps, as has been observed in F. erratica and $F$. gascognensis.

Thus, these species (F. erratica, F. cirrata, $F$. mediterranea, $F$. biscayensis, $F$. amoureuxi and $F$. gascognensis) would constitute a group of species having a pair of frontal palps, 1-3 pairs of cirri/branchiae, spinulose or serrated (not crossbarred) notochaetae, etc., and would differ from the other group of species (F. papillata, F. minuta, $F$. mexicana and F. macrochaeta) characterized by the absence of cirri/branchiae and the presence of crossbarred notochaetae.

At this point there are two possibilities. The first is to include all the Flabelligella-like species in the genus Flabelligella, in which case it would be necessary to emend the definition of the genus of Orensanz (1974), in relation to the number of branchiae. The second is, following Gillet (2001), to 
TABLE 1. - A comparison of some characters in existing species in the genus Flabelligena Gillet, 2001. (Adapted from Gillet, 2001).

\begin{tabular}{|c|c|c|c|c|c|c|c|c|}
\hline Species & Type locality & $\begin{array}{l}\text { Depth } \\
\text { (m) }\end{array}$ & $\begin{array}{c}\text { Pair of } \\
\text { branchiae }\end{array}$ & $\begin{array}{c}\text { Pair of large } \\
\text { ventral papillae }\end{array}$ & Chaetigers & Notochaetae & Neurochaetae & Eyes \\
\hline $\begin{array}{l}\text { F. cirrata } \\
\text { (Hartman and } \\
\text { Fauchald, 1971) }\end{array}$ & $\begin{array}{l}\text { New England } \\
\text { (NW Atlantic) }\end{array}$ & $466-530$ & 1 & absent & $17-24$ & serrated 1-2 & composite $4-8$ & 0 \\
\hline $\begin{array}{l}\text { F. amoureuxi } \\
\text { Gillet (2001) }\end{array}$ & $\begin{array}{l}\text { Crozet Islands } \\
\text { (Indian Ocean) }\end{array}$ & $215-980$ & 1 & absent & 30 & spinulose 1 & composite 3-5 & 0 \\
\hline $\begin{array}{l}\text { F. erratica } \\
\text { (Orensanz, 1974) }\end{array}$ & $\begin{array}{c}\text { Argentina } \\
\text { (SW Atlantic) }\end{array}$ & 288 & 1 & $\begin{array}{l}\text { one pair, between } \\
\text { chaetigers 6-7 }\end{array}$ & $20-30$ & spinulose 1 & composite 1-3 & 2 \\
\hline $\begin{array}{l}\text { F. biscayensis } \\
\text { (Kolmer, 1985) }\end{array}$ & $\begin{array}{l}\text { Bay of Biscay } \\
\text { (NE Atlantic) }\end{array}$ & 2.210 & 2 & absent & incomplete (11) & spinulose $2-5$ & composite 1 & 0 \\
\hline $\begin{array}{l}\text { F. mediterranea } \\
\text { (Kolmer, 1985) }\end{array}$ & $\begin{array}{l}\text { Mediterranean } \\
\text { Sea }\end{array}$ & 4.690 & 2 & $\begin{array}{l}\text { one pair, between } \\
\text { chaetigers } 4-5\end{array}$ & incomplete (8) & spinulose $2-5$ & composite $2-4$ & 0 \\
\hline $\begin{array}{l}\text { F. gascognensis } \\
\text { sp. nov. }\end{array}$ & $\begin{array}{l}\text { Bay of Biscay } \\
\text { (NE Atlantic) }\end{array}$ & $545-1113$ & 3 & $\begin{array}{c}\text { one pair, between } \\
\text { chaetigers } 6-7\end{array}$ & incomplete (25) & spinulose ?-4 & composite $2-4$ & 0 \\
\hline
\end{tabular}

separate the species lacking branchiae and provided with cross-barred notochaetae (Flabelligella), from the species with branchiae and spinulose or serrated notochaetae (Flabelligena). This separation could help to shed light on the confusion about the species of the genus Flabelligella, but to carry it out it would be necessary to emend the diagnosis of the genus Flabelligena slightly in relation to the consideration of the nature of the latero-dorsal appendages (branchiae and not palps) and the number of them (1-3). However, in this case the confusion could be moved to the genus Flabelligena and Macrochaeta. The main difference between the two genera would be reduced to the different "habitus" of Flabelligena, especially the lack of distinct body regions and the retractile anterior region.

It is clear that the family Acrocirridae needs a revision, but this is not the aim of this work. However, we are convinced that until this revision is carried out the separation of Flabelligella-like species into two different genera can be useful.

\section{Genus Flabelligena Gillet, 2001}

Acrocirrids with prostomium without cephalic cage, anterior region retractile and lacking distinct body regions. With various (1-3) pairs of branchiae. Neuropodia have composite falcigerous chaetae and notopodia have simple spinulose or serrated, not cross-barred, chaetae.

The number of currently known species belonging to the genus Flabelligena would be six (Table 1). Flabelligena species are found mainly in bathyal and abyssal depths. F. cirrata and F. erratica have been recorded from the northwest and southwest Atlantic respectively; F. amoureuxi from the Indian Ocean, and $F$. mediterranea from abyssal depths of the Mediterranean Sea. Two species, F. biscayensis and $F$. gascognensis, have been recorded from the Bay of Biscay.

\section{Key of the genus Flabelligena}

1 - One pair of branchiae .........................................2 More than one pair of branchiae ...................... 4

2 - One pair of large ventral papillae between chaetigers 6 and 7 ................................ erratica Large ventral papillae absent............................. 3

3 - Notochaetae spinulose ...................... amoureuxi Notochaetae serrated .............................. cirrata

4 - Two pairs of branchiae ........................................ Three pairs of branchiae. One pair of large ventral papillae between chaetigers 6 and $7 \ldots \ldots .$. F. gascognensis sp. nov.

5 - One pair of ventral papillae between chaetigers

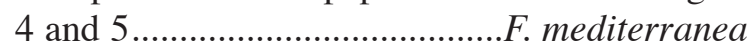
Large ventral papillae absent ........F. biscayensis

\section{ACKNOWLEDGEMENTS}

Thanks are due to the Laboratoire de Biologie des Invertébrés Marins (BIMM-MNHN, Paris) for the loan of the sieving equipment, to the French Comité Interrégional Manche Atlantique (CIRMAT) - Centre National de la Recherche Scientifique 
(CNRS) for logistical support and loan of an epibenthic dredge, to the crews of the RV "Côte d'Aquitaine" and RV "Côtes de la Manche for their helpful assistance at sea, to A. Urzelai, I. Esteban and I. Zabala (INSUB, San Sebastian) for their helpful contribution to the sorting of Capbreton samples, to Dr. P. Gillet (UCO) for kindly providing bibliography, to R. Andrade and S. Fernández (UPV-EHU) for the SEM photograps, and to the anonymous reviewers whose ideas and suggestions have improved this work. The French CIRMAT-CNRS supported the 1988-89 CAPBRETON cruises. Special thanks to Dr. Jean Claude Sorbe, director of the Capbreton research, and to Dr. P. Carbonel, chief scientist of the French OXYBENT programme.

\section{REFERENCES}

Banse, K. - 1969. Acrocirridae n. fam. (Polychaeta Sedentaria). J. Fish. Res. Bd. Canada, 26: 2595-2620.

Blake, J.A. - 1996. Chapter 2. Family Acrocirridae Banse, 1969. In: J.A. Blake, B. Hilbig and P.H. Scott (eds.), Taxonomic Atlas of the Benthic Fauna of the Santa Maria Basin and the Western Santa Barbara Channel. Vol. 7, pp. 25-29. Santa Barbara Museum of Natural History, California, USA.

Dauvin, J.C., J.C. Sorbe and J.C. Lorgere. - 1995. Benthic Boundary Layer macrofauna from the upper continental slope and the Cap Ferret canyon (Bay of Biscay). Oceanol. Acta,
18(1): 113-122

Fauchald, K. - 1972. Benthic polychaetous annelids from deep water off western Mexico and adjacent areas in the eastern Pacific ocean. Allan Hancock Monogr. Mar. Biol, 7: 1-575.

Fauchald, K. - 1977. The polychaete worms. Definitions and keys to the orders, families and genera. Natural History Museum of Los Angeles County, Sci. Ser. 28: 1-188.

Gillet, P. - 2001. Flabelligena amoureuxi, new genus, new species (Polychaeta: Acrocirridae) from Crozet Islands (Indian Ocean). Bull. Mar. Sci., 68: 125-131.

Hartman, O. - 1965. Deep-water benthic polychaetous annelids off New England to Bermuda and other north Atlantic areas. Allan Hancock Found. Publ. Occ. Pap., 28: 1-378.

Hartman, O. - 1971. Abyssal polychaete annelids from the Mozanbique Basin off southeast Africa, with a compendium of abyssal polychaetous annelids from world-wide areas. J. Fish. Res. Bd. Canada, 28: 1407-1428.

Hartman, O. and K. Fauchald. - 1971. Deep-water benthic Annelids off New England to Bermuda and other north Atlantic areas. Part. II. Allan Hancock Monogr. Mar. Biol., 6: 1-327.

Kolmer, D.W. - 1985. Acrocirridae (Annélides Polychètes) abyssaux: Golfe de Gascogne et Mediterranée. In: L. Laubier and C. Monniot (eds.), Peuplements profonds du Golfe de Gascogne Campagne BIOGAS, pp. 355-364. Ifremer, France.

Ligth, W.J. - 1978. Reexamination of the species referred to the genus Flabelliderma Hartman (Polychaeta: Flabelligeridae and Acrocirridae). Proc. Biol. Soc. Wash., 91(3): 681-690.

Orensanz, J.M. - 1974. Poliquetos de la provincia biogeográfica argentina. X. (Acrocirridae). Neotropica, 20(63): 113-118.

Pettibone, M.H. - 1982. Classification of Polychaeta. In: S.P. Parker (ed.), Synopsis and Classification of Living Organisms, pp. 3-43. McGraw-Hill, New-York, USA.

Wolf, P.S. - 1984. Chapter 13. Family Acrocirridae Banse, 1969. In: J.M. Uebelacker and P.G. Johnson (eds.), Taxonomic guide to the polychaetes of the northern Gulf of Mexico. Vol. 2, pp. 13.1-13.7. Barry A. Vittor and Associates, Inc, Mobile, Alabama, USA.

Received July 1, 2002. Accepted November 24, 2004. 
